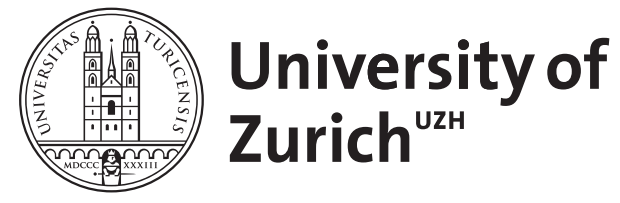

\title{
The Derveni Papyrus on Heraclitus (Col. IV)
}

\author{
Burkert, Walter
}

DOI: https://doi.org/10.1515/9783110260533.361

Posted at the Zurich Open Repository and Archive, University of Zurich

ZORA URL: https://doi.org/10.5167/uzh-59629

Book Section

Published Version

Originally published at:

Burkert, Walter (2011). The Derveni Papyrus on Heraclitus (Col. IV). In: Jaureguizar, E; Jiménez San Cristóbal, A I; Luján Martínez, E R; Hernández, R M; Santamaría Álvarez, M A; Torallas Tovar, S. Tracing Orpheus. Studies of the orphic fragments. Berlin: De Gruyter, 361-364.

DOI: https://doi.org/10.1515/9783110260533.361 


\title{
58. The Derveni Papyrus on Heraclitus (col. IV)
}

\author{
WALTER BURKERT \\ Universität Zürich
}

When Martin West, in 1972, copied the fragments of the Derveni Papyrus that were on exhibition in the museum of Thessaloniki, he at once recognized Heraclitus B 3 in $\mathrm{AN} \Theta \mathrm{P} \Omega$... EYPO $\Sigma \Pi \mathrm{O} \Delta \mathrm{O} \Sigma$. Some years later Kyriakos Tsantsanoglou made known some more lines of this fragment, so that two famous quotations of Heraclitus appeared, B 3 and B 94, apparently belonging together. ${ }^{1}$ It was only then that Mouraviev read in fact HPAK $\Lambda$ EITO $\Sigma$ in line 5. But even so this column, as it now appears in Kouremenos - Parássoglou - Tsantsanoglou (2006) and with additional supplements in Bernabé (2007), remains enigmatic. The context is unclear, as the earlier columns are still more fragmentary. The text of "Orpheus" has not yet been touched - the commentary starts in col. VII. It is great to have these early testimonies for Heraclitus. But what is it about?

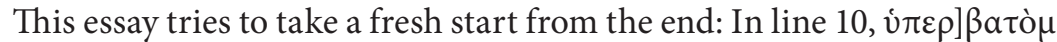

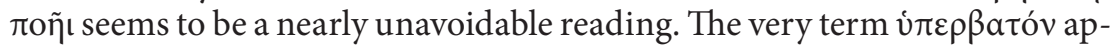
pears also in col. VIII 6, and in Plato's Protagoras (343e), one of the earliest texts of detailed literary interpretation we have. Evidently it has already the meaning defined in later rhetoric (Quint. Inst. 8.6.65 opportuna ordinis mutatio): the author has 'overstepped' a word which results in an uncommon word order; the reader must recognize this and reconstruct the meaning in context to bring out the sense. In Plato's Protagoras, within the interpretation of the famous Simonides poem (fr. $542 P M G$ ), Socrates insists that

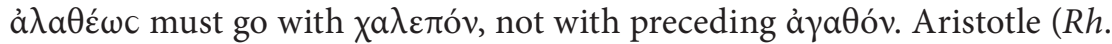
1407b 14) discusses a problem of the kind right in reference to Heraclitus $B$ 1 , although without the term; he speaks of the problem of punctuation in-

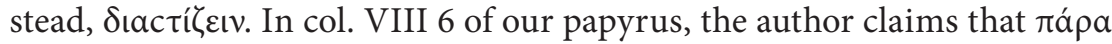

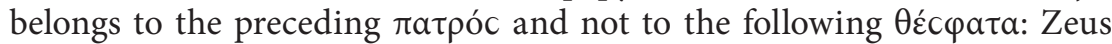
receives power "from the father", he does not act "against oracles"; such

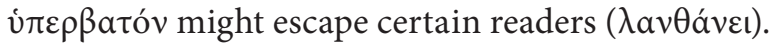

1 Bibliography on the Heraclitus fragment: Burkert (1983 and 1993); Mouraviev (1985); Sider (1987); Parássoglou - Tsantsanoglou (1988). Commentaries of the Derveni Papyrus: Jourdan (2003); Betegh (2004). Commented editions: Kouremenos - Parássoglou - Tsantsanoglou (2006); Bernabé (2007). 


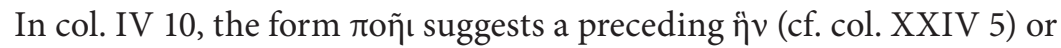

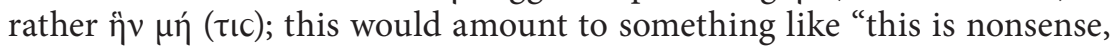
unless one makes the appropriate change of word order".

In fact this seems to go together with a likely supplement right at the

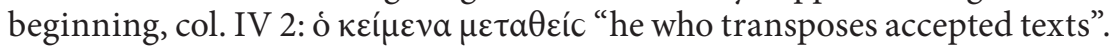
One might hesitate to translate $\kappa \varepsilon i ́ \mu \varepsilon v o v$ here directly with 'text' - common in later commentaries -, but starting from expressions such as vó

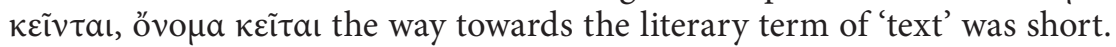
The following phrase can be reconstructed in accordance.

The 'text' dealt with here is the quotation of Heraclitus. So which change of word order does the author advocate?

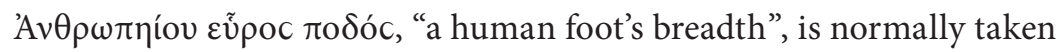
as a predicate of Helios, i.e. a statement about his size; and modern interpreters of Heraclitus go on to discuss either the primitive astronomy of Heraclitus or else his wilful protest against Anaximander's calculation of distances and sizes (Anaximander A 19 = Eudemus fr. 146 Wehrli). Such a statement indeed would have been an affront already for Heraclitus' contemporaries; somewhat later Anaxagoras (A 77) had found the explanation of the lunar eclipse: we see the earth's shadow, cast by the sun, on the surface of the moon - a clue in fact to imagine the sizes of heavenly bodies (cf. Arist. Cael. 297b 28). The Derveni author clearly is post-Anaxagorean.

What could be the effect of a "change of word order" here? Let the distance of "a human foot" belong to what follows, and you get: Not even by one human foot's breadth will Helios surpass the boundaries established for his course. This makes primitive astronomy disappear.

A reconstruction of the text remains hazardous. It means to abandon the supplements presented by Kouremenos, Bernabé and others.

Here is a tentative transcript of the text preserved, following Kouremenos (68), with checking his photographs:

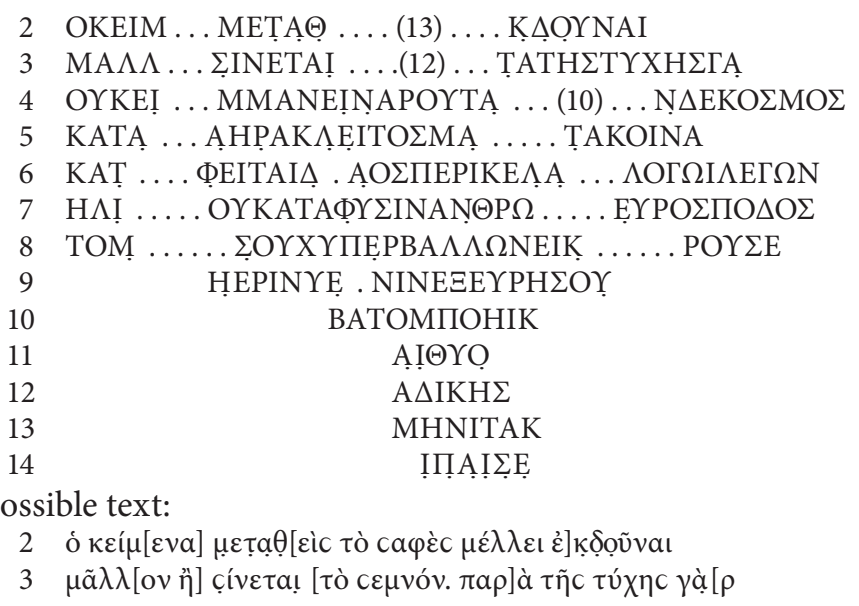




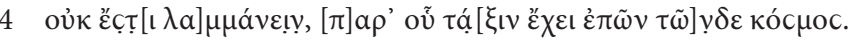

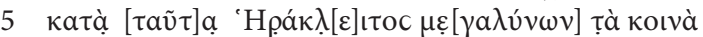

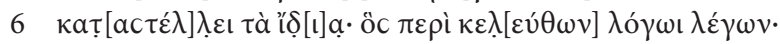

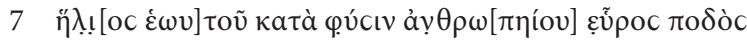

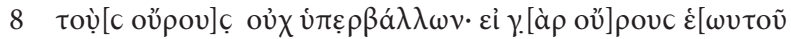

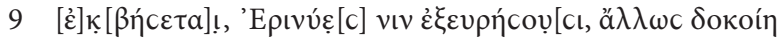

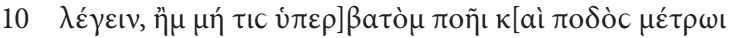

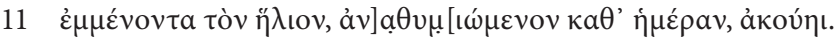

This is far from certain. One new letter added or clearly read may change the whole. It is good to remember how for Antiphon F $44 \mathrm{DK}$, a comparatively simple, unpretentious text, one little piece of papyrus added later (1984: POxy. $52 \mathrm{nr}$. 3647) brought half a dozen of corrections.

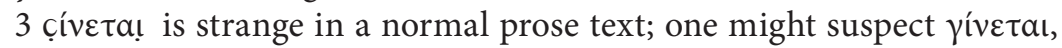
with various possible supplements.

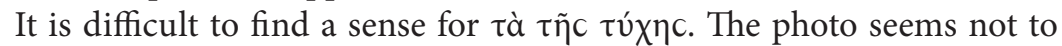
exclude $\pi \alpha \rho] a ́$.

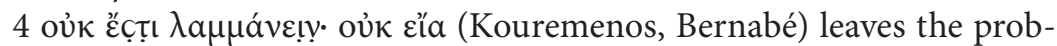
lem who should be the subject here; Orpheus has not yet been mentioned in the extant letters, Heraclitus enters in line 5. The photo shows no trace of the fifth letter.

A rhetorical question would be unique within this text; hence the attempt at $\pi \alpha \rho$ ' oṽ; $\dot{\alpha} \varphi$ ' oṽ seems excluded by a very clear $\rho$.

кócuoc: The lacuna admits various supplements. That cosmic order should be mentioned has been a dominating idea of interpreters; but it is only within the Heraclitus quotation that Helios makes his entrance. If in-

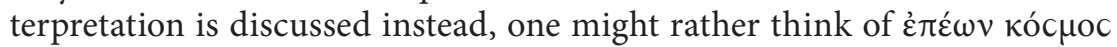
(Democritus B 21, cf. Solon fr. 1.2 West; Parmenides B 8.52); $\tau \tilde{\omega} y \delta \varepsilon$ remains enigmatic - it must refer to something preceding col. IV 1.

$5 \mathrm{ME}$ instead of MA is read by Bernabé, who restores $\mu \varepsilon \gamma \alpha$ á $\lambda \alpha$; the corresponding verb is inserted here, to contrast with the verb in the next line;

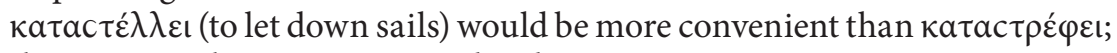
the traces in the papyrus must decide.

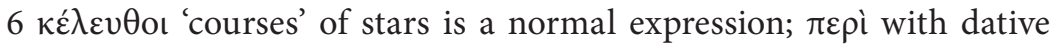
seems possible, perhaps more 'for the sake of' than just 'about'. It was Anax-

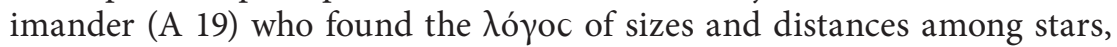
Eudemus fr. 146 Wehrli = Simpl. Cael. 471.4 .

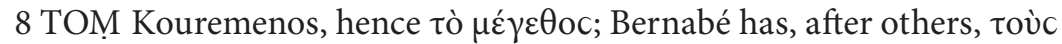
oúpouc; oũ poc is used by Heraclitus in an astronomical context, B 120.

Later in the line Kouremenos has EIK, supplemented to ci kai; Bernabé's $\gamma$ à $\rho$ is much more attractive to connect the two Heraclitean sayings, and seems possible according to the photo.

$9 \kappa$ in Bernabé, without comment. 
11 Restoration is hopeless: Kouremenos presents 5 letters, three of them uncertain; there remains $\Theta Y$. By a very slight chance this could indicate the doctrine of Heraclitus developed in B 6 and A 1.10-11, A 12.

The translation would be:

He who transposes an established text will rather bring out the clear meaning than destroy the prestige. For it is impossible to get by pure chance, from where the composition of these verses has its order. In this sense Heraclitus, making great the common (perceptions), reduces the individual ones; speaking on the calculation of (stars') courses:

"Helios, according to his own nature, a human foot's breadth boundaries not surpassing; for if he will step outside his own boundaries, Erinyes will find him out" (saying this, Heraclitus) would speak nonsense, unless one makes a different word order and understands: even by measure of one foot Helios stays in his boundaries, as he rises in vapour every day.

It is hardly necessary to repeat: this is uncertain; we desperately would like to have just a few more letters. Some will criticize certain expressions, others will regret if one of those memorable paradoxes of Heraclitus' is made to disappear, even if the Derveni author, of course, need not be right; Aetius (2.21.4 = B 5) records Heraclitus' one-foot-sun without comment. Nevertheless it might be worthwhile to follow the Derveni author in his strolls within a Presocratic world picture, and his footing in the tricks of interpretation.

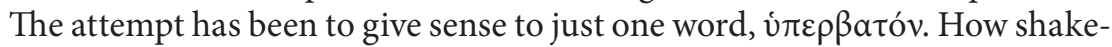
able interpretations of fragments are, this may well be the clearest result.

\section{Bibliography}

Bernabé, A. 2007: Poetae Epici Graeci. Testimonia et fragmenta. Pars II, Orphicorum et Orphicis similium testimonia et fragmenta, fasc. 3: Musaeus - Linus - Epimenides Papyrus Derveni - Indices, Berolini et Novi Eboraci.

Betegh, G. 2004: The Derveni Papyrus. Cosmology, Theology, and Interpretation, Cambridge.

Burkert, W. 1983: «Eraclito nel Papiro di Derveni. Due nuove testimonianze», Atti del Symposium Heracliteum (1981), Rossetti, L. (ed.), Roma, 37-42.

- 1993: «Heraclitus and the Moon: The New Fragments in P.Oxy. 3710», Illinois Classical Studies 18, 49-55 = Kleine Schriften, VIII, Göttingen, 2008, 28-34.

Jourdan, F. 2003: Le papyrus de Derveni, Paris.

Kouremenos, Th. - Parássoglou, G. M. - Tsantsanoglou, K. 2006: The Derveni Papyrus, Firenze.

Mouraviev, S.N. 1985: «The Heraclitean Fragment of the Derveni Papyrus», ZPE 61, $131-132$.

Parássoglou, G. M. - Tsantsanoglou, K. 1988: «Heraclitus in the Derveni Papyrus», Aristoxenica, Menandrea, Fragmenta Philosophica, Firenze, 125-133.

Sider, D. 1987: «Heraclitus B 3 and 94 in the Derveni Papyrus», ZPE 69, 225-228. 